\title{
Primary energy consumption in the power generation sector and various market structures: a modelling approach
}

\section{Introduction}

Throughout the European Union, primary energy sources as well as power generation fuel-mixes are highly diversified. Such diversification results from several reasons. In some countries historically shaped fuel-mixes have been maintained, while in others a substantial change was observed, mostly due to the influence of energy policies. The first group includes power sectors that rely strongly on nuclear (France), hydro (Norway), natural gas (Italy), or coal power generation (Poland). The second group consists of various countries that have managed to change their fuel-mixes mainly through the implementation of energy policy instruments aimed at achieving desired fuel-mixes (Spain, Germany, UK). One of the advantages of a diversified fuel-mix is the ability of the power system to respond to changing fuel prices. For instance, in the UK, in 2012, the share of natural gas in electricity generation-mix amounted to $27.5 \%$, and when compared to 2011 the gas consumption fell by $31.7 \%$. In the same period, a strong growth in coal use for power generation of $31.9 \%$ was recorded (Szurlej and Janusz 2013; Iwicki et al. 2014).

Apart from fuel prices' fluctuations and climate regulations that contributed to changes in power generation-mixes, there have also been other important changes in the power sectors. Some countries decided to introduce competition and privatisation in their power sectors

* Professor, Mineral and Energy Economy Research Institute, Polish Academy of Sciences Energy and Environmental Policy Division, Krakow, Poland; e-mail: kaminski@meeri.pl 
(like the UK). Other countries, such as France or Sweden, maintain a significant influence of the state over power generation companies.

As regards Poland, coal continues to play a crucial role as the key primary energy carrier used for heat and power generation. This is due to the fact that Poland is the biggest hard coal producer in Europe and, naturally, this energy carrier has been consumed extensively for decades (Siemek et al. 2010). The electricity generation fuel mix indicates that, in Poland, renewables and natural gas-based power plants produced only $7.2 \%$ of electricity (Fig. 1).

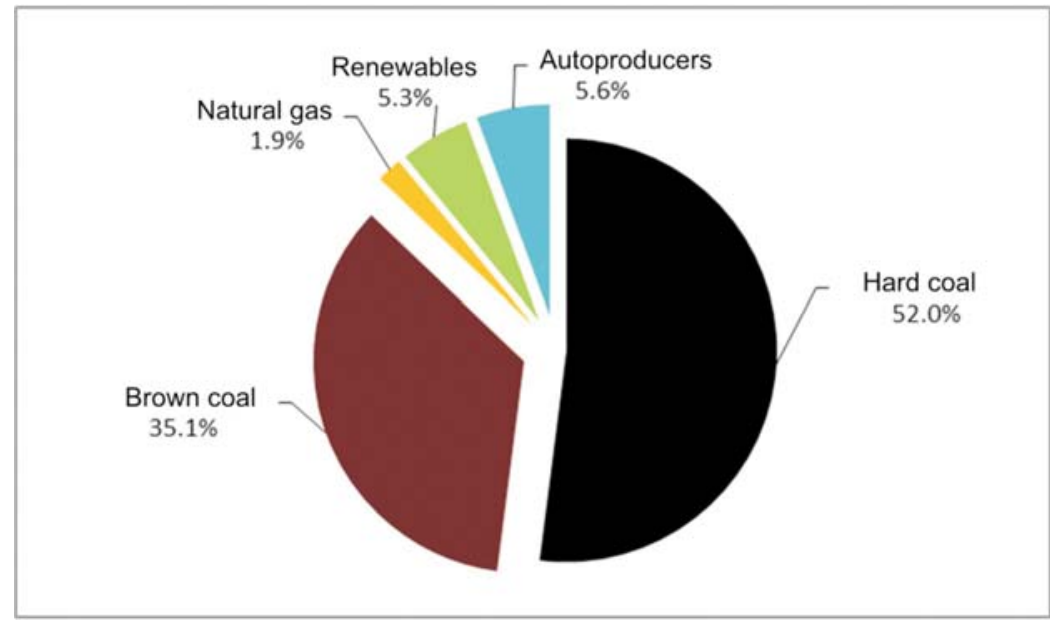

Fig. 1. Electricity generation fuel-mix, 2013 [\%]

Source: PSE 2014

Rys. 1. Struktura wytwarzania energii elektrycznej, 2013 [\%]

An analysis of the total coal sales to the Polish public power sector shows that for the period 2002-2008 coal consumption increased year by year. Then, the level of coal sales plummeted, reaching approx. $35 \mathrm{Mt}$ in 2010. After an increase in sales in 2011, it dropped again to the same level in 2012 (Fig. 2).

Owing to the fact that with the liberalisation of the power sector there might exist various market structures, improvements are required in the methods that are applied in order to analyse fuel and power sectors. Inclusion of environmental or technical aspects of electricity generation is currently insufficient to study fuel-power systems interactions.

Considering the aforementioned, the main purpose of this paper is to develop the concept of a computable model designed to carry out analyses of primary energy consumption in the power sector. Although there have already been some efforts to model power generation systems under the Mixed Complementarity Problem (MCP) approach, it would appear that previous works have not approached the issue of fuel supplies in the context of varying market structures. This paper is intended to fill that gap. 


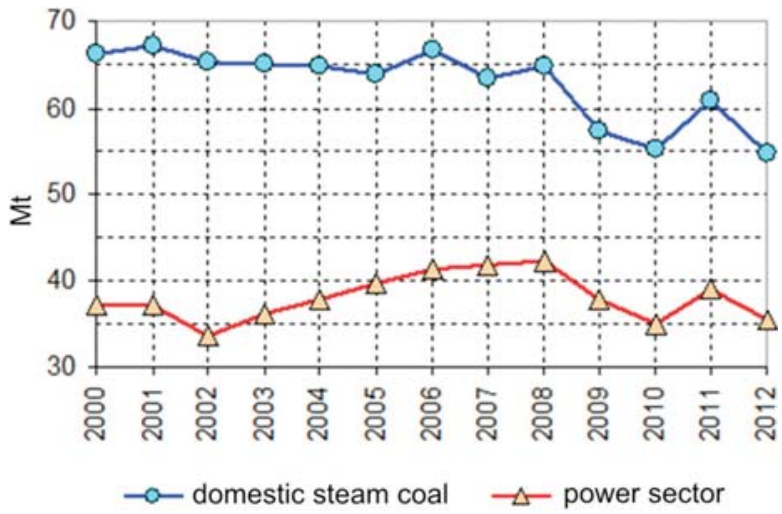

Fig. 2. Coal sales to the Polish public power sector and the total sales of coal in Poland Source: Gawlik, ed., et al. 2013

Rys. 2. Sprzedaż węgla do energetyki zawodowej oraz całkowita sprzedaż węgla w Polsce

The remainder of the paper is structured as follows: In section 2 the model concept for analyses of primary energy supplies to the power sector under various market structures is discussed. Section 3 provides the mathematical expression of the model and section 4 presents key model capabilities. The paper ends with conclusions that outline main findings (section 5).

\section{The model concept for analyses of primary energy supplies to the power sector given various market structures}

After reviewing several achievements in the modelling of fuel supplies to power generation, the following assumptions were formed. The developed model should explicitly distinguish between two wholesale electricity markets, namely the day-ahead, and the bilateral one. The model should be able to address various market structures in the context of thermal power generation, as well as generation based on renewable sources, with particular attention paid to fuel supplies. In addition, it was assumed that all firms are competing in the power markets and should be reflected in the model as individual companies which produce electricity using differing technologies.

The model developed in this article is based upon the game theory Cournot approach with the inclusion of conjectural variations (CV) (Varian 1992; Tirole 1988). Under this approach, power companies change their production in response to the decisions of other power companies in order to maximize their profits. This choice allows the representation of a wider range of market structures from perfect competition, to oligopolies or cartels. The model has been formulated as a Mixed Complementarity Problem (MCP), a general mathematical framework which is particularly well suited for modelling energy systems. The equations are defined by the Karush-Kuhn-Tucker conditions (KKT), reflecting the 
conditions for profit maximization of each power company and market-clearing conditions. A similar approach has been also applied to market power analyses of the power sector (please compare: Kamiński 2011, 2012, 2014).

\section{The mathematical expression of the model for analyses of primary energy supplies to the power sector given various market structures}

\subsection{Naming conventions}

The following tables describe the sets, parameters, and variables used in the subsequent sections. Each table contains the parameter's name followed by its units and a brief description. In addition, parameters are grouped depending on the problem that they are associated with.

Table 1. Sets

Tabela 1. Zbiory

\begin{tabular}{|c|l|}
\hline Sets & \multicolumn{1}{|c|}{ Description } \\
\hline$M=\{\mathrm{i}\}$ & Wholesale electricity markets (DAM: Day-Ahead-Market and OTC: Over-The-Counter) \\
\hline$F=\{f\}$ & Power generation companies and Combined Heat and Power (CHP) companies \\
\hline$P P=\{p p\}$ & Power plants and CHP plants (individual units) \\
\hline$D=\{d\}$ & Days (7 in this model) \\
\hline$L=\{l\}$ & Loads (24 hours in this model) \\
\hline$P=\{p\}$ & Pollutants \\
\hline$T=\{t\}$ & Power generation technologies \\
\hline$S R=\{s r\}$ & Technologies receiving remuneration (premiums) (subset of $T$ ) \\
\hline$R E=\{r e\}$ & Renewable generation technologies (subset of $T$ ) \\
\hline$F U=\{f u\}$ & Fuels, primary energy carriers \\
\hline
\end{tabular}

Table 2. Parameters

Tabela 2. Dane

\begin{tabular}{|c|c|c|l|}
\hline Problem & Parameters & Unit & \multicolumn{1}{c|}{ Description } \\
\hline \multirow{2}{*}{$\begin{array}{c}\text { Power } \\
\text { plant-related }\end{array}$} & $o c_{p p, m}$ & EUR/MWh & $\begin{array}{l}\text { Other costs, non-fuel-related, non-emissions-related of power } \\
\text { plant } p p \text { (Short Run Marginal Cost if } m=\text { DAM, Long Run } \\
\text { Marginal Cost if } m=\text { OTC) }\end{array}$ \\
\cline { 2 - 4 } & $o_{p p, f}$ & $\%$ & Ownership indicator (1 if $f$ owns $p p, 0$ otherwise) \\
\hline
\end{tabular}


Table 2. cont.

Tabela 2. cd.

\begin{tabular}{|c|c|c|c|}
\hline Problem & Parameters & Unit & Description \\
\hline \multirow{11}{*}{$\begin{array}{c}\text { Power } \\
\text { plant-related }\end{array}$} & $t_{p p, t}$ & $\%$ & Technology indicator ( 1 if $p p$ is of type $t ; 0$ otherwise) \\
\hline & $c i_{p p}$ & MW & Installed capacity of power plant $p p$ \\
\hline & $a f_{p p, d, l}$ & $\%$ & Availability factor of power plant $p p$ during $d$ and $l$ \\
\hline & $e_{p p}$ & $\%$ & Efficiency of power plant $p p$ \\
\hline & $f p_{m, t}$ & EUR/MWh & Fuel price for power generation technology $t$ in market $m$ \\
\hline & $r u_{p p}$ & $\mathrm{MWh} / \mathrm{h}$ & Ramp-up rate of power plant $p p$ \\
\hline & $r d_{p p}$ & $\mathrm{MWh} / \mathrm{h}$ & Ramp-down rate of power plant $p p$ \\
\hline & $p r_{t, m}$ & EUR/MWh & $\begin{array}{l}\text { Premium received by certain technologies for power generation } \\
\text { technology } t \text { in market } m\end{array}$ \\
\hline & $f t_{t, f u}$ & $\%$ & Fuel $f u$ used by technology $t$ \\
\hline & $i_{p p, m}$ & $\%$ & $\begin{array}{l}\text { Intermittent technologies } \\
(1 \text { if } p p \text { is allowed to produce for market } m ; 0 \text { otherwise) }\end{array}$ \\
\hline & $p l$ & $\%$ & Production and transmission losses \\
\hline \multirow{3}{*}{$\begin{array}{l}\text { Emission- } \\
\text {-related }\end{array}$} & $e r_{p p, p}$ & $\mathrm{Mg} / \mathrm{MWh}$ & Specific emissions of pollutant $p$ produced by power plant $p p$ \\
\hline & $p c_{f, p}$ & $\mathrm{Mg}$ & Emissions cap of pollutant $p$ for firm $f$ \\
\hline & $\operatorname{exopp}_{p}$ & $\mathrm{EUR} / \mathrm{Mg}$ & Exogenous permit price for pollutant $p$ \\
\hline $\begin{array}{l}\text { Renewable- } \\
\text {-related }\end{array}$ & $r t_{f}$ & $\%$ & Renewable production target of firm $f$ \\
\hline \multirow{8}{*}{$\begin{array}{l}\text { Hydro- } \\
\text {-related }\end{array}$} & $h i_{f, d, l}$ & MWh & Hydro inflows \\
\hline & $s m_{f}$ & $\mathrm{MWh}$ & Minimal level of energy stored by firm $f$ \\
\hline & $s c_{f}$ & MWh & Storage capacity of firm $f$ \\
\hline & $s o c_{f}$ & MWh & Storage discharging capacity of firm $f$ \\
\hline & vow & EUR/MWh & Cost of discharging from storage \\
\hline & $p c_{f}$ & MWh & Pumping capacity of firm $f$ \\
\hline & $p e_{f}$ & $\%$ & Pumping efficiency \\
\hline & $s_{m}$ & $\%$ & $\begin{array}{l}\text { Binary parameter for including/excluding storage input and } \\
\text { output in the equations for DAM/OTC ( } 1 \text { for DAM; } 0 \text { for OTC) }\end{array}$ \\
\hline \multirow{3}{*}{$\begin{array}{l}\text { Demand- } \\
\text {-related }\end{array}$} & $e l_{c, m}$ & $\%$ & Elasticity of demand in market $m$ \\
\hline & $D_{m, d, l}^{*}$ & MWh & Reference demand in market $m$ during $l$ in day $d$ \\
\hline & $P_{m, d, l}^{*}$ & EUR/MWh & Reference price in market $m$ during $l$ in day $d$ \\
\hline $\begin{array}{c}\text { Market } \\
\text { power-related }\end{array}$ & $c v_{f, m, l}$ & $\%$ & Conjectural variation of firm $f$ in market $m$ during $l$ \\
\hline \multirow{3}{*}{$\begin{array}{l}\text { Selected } \\
\text { output } \\
\text { parameters }\end{array}$} & $f_{c_{f u}}$ & GJ & $\begin{array}{l}\text { Primary energy carrier (fuel) } f u \text { consumption in the power sector } \\
\text { in the analysed period }\end{array}$ \\
\hline & $s_{f, m, d, l}$ & $\mathrm{MWh}$ & Sales by firm $f$ in market $m$ during $l$ in day $d$ \\
\hline & $\Pi_{F}$ & EUR & Profit obtained by firm $f$ during the simulation horizon \\
\hline
\end{tabular}


Table 3. Variables

Tabela 3. Zmienne

\begin{tabular}{|c|c|c|l|}
\hline Problem & Variables & Unit & \multicolumn{1}{|c|}{ Description } \\
\hline \multirow{4}{*}{ Company } & $G_{p p, m, d, l}$ & $\mathrm{MWh}$ & Power generation for market $m$ by power plant $p p$ during $l$ in day $d$ \\
\cline { 2 - 5 } & $S I_{f, d, l}$ & $\mathrm{MWh}$ & Pumping for storage by $f$ during $l$ in day $d$ \\
\cline { 2 - 5 } & $S O_{f, d, l}$ & $\mathrm{MWh}$ & Production from $f$-owned storage capacity during $l$ in day $d$ \\
\cline { 2 - 5 } & $S L_{f, d, l}$ & $\mathrm{MWh}$ & Storage level of $f$-owned storage capacity during load $l$ in day $d$ \\
\hline \multirow{2}{*}{ Prices } & $P_{m, d, l}^{E}$ & EUR/MWh & Price of electricity in market $m$ during $l$ in day $d$ \\
\hline
\end{tabular}

\subsection{Generation companies' problems}

In the case of power generation companies, the profit is calculated as the difference between incomes and incurred costs. In this model, income is obtained only from selling electricity in the power markets. Costs are related to generation and storage. Therefore, the profit equation is expressed as follows:

\begin{tabular}{|l|l|}
\hline & $\operatorname{Max} \Pi_{F}\left(G_{p p, m, d, l} \geq 0 ; S I_{f, d, l} \geq 0\{\right.$ only $D A M\} ; S O_{f, d, l} \geq 0\{$ only DAM\} $)=$ \\
& $\sum_{f, d, l, m}\left(P_{m, d, l}^{E} \cdot\left(\sum_{p p}\left(G_{p p, m, d, l} \cdot o_{p p, f} \cdot i_{p p, m}\right)\right)\right)+\sum_{f, d, l, m}\left(P_{m, d, l}^{E} \cdot\left(S O_{f, d, l}-S I_{f, d, l}\right) \cdot s_{m}\right)$ \\
& $-\sum_{f, d, l, p p, m}\left(G_{p p, m, d, l} \cdot\left(\sum_{p}\left(2 r_{p p, p} \cdot \operatorname{exopp} p_{p}\right)+o c_{p p, m}+\frac{\sum_{t}\left(f p_{m, t} \cdot t_{p p, t}\right)}{e_{p p}}\right) \cdot o_{p p, f}\right)$ \\
& $+\sum_{f, d, l, p p, m, t}\left(G_{p p, m, d, l} \cdot p r_{t, m} \cdot t_{p p, t} \cdot o_{p p, f}\right)-\sum_{f, d, l}\left(\right.$ vow $\left.\cdot S O_{f, d, l}\right)$
\end{tabular}

The profit function is constrained by a series of restrictions related to sales balances, available capacity, limitations on storage levels and the available storage capacity, inter-temporal balances linking hydro inflows, pumping, storage levels, and discharging.

The first constraint imposes the (positive) sign of the amount of sold electricity:

\begin{tabular}{|c|c|}
\hline F2 & $-\sum_{p p}\left(G_{p p, m, d, l} \cdot o_{p p, f} \cdot i_{p p, m}\right)-\left(S O_{f, d, l}-S I_{f, d, l}\right) \cdot s_{m} \leq 0$ \\
\hline
\end{tabular}

Each power plant's generation (in a given hour) is limited by its installed capacity multiplied by the availability factor:

$$
\sum_{m}\left(G_{p p, m, d, l}\right)-c i_{p p} \cdot a f_{p p, d, l} \leq 0
$$


Regarding hydropower, there are five relevant constraints. The first constraint establishes the lower bound of the amount of energy stored:

\begin{tabular}{|l|c|}
\hline $\mathbf{F} 4$ & $s m_{f}-S L_{f, d, l} \leq 0$ \\
\hline
\end{tabular}

That amount of stored energy is also capped by the capacity of the reservoirs:

\begin{tabular}{|c|c|}
\hline F5 & $S L_{f, d, l}-s c_{f} \leq 0$ \\
\hline
\end{tabular}

However, not only is the energy stored in the reservoirs bounded, but the pumped storage units have a limited pumping capacity:

\begin{tabular}{|c|c|}
\hline F6 & $S I_{f, d, l}-p c_{f} \leq 0$ \\
\hline
\end{tabular}

While the amount of energy that may be obtained from discharge is also limited:

\begin{tabular}{|l|l|}
\hline $\mathbf{F} 7$ & $\mathrm{SO}_{f, d, l}-\operatorname{soc}_{f} \leq 0$ \\
\hline
\end{tabular}

Finally, for each period, the levels of stored energy in the previous period plus the inflows (from pumping and any other source) must be equal to the stored energy remaining in the reservoirs plus the amount of energy obtained from discharge:

F8

$$
S L_{f, d, l}-S L_{f, d, l-1}-\sum_{l=H 1}^{l=H 24} S L_{f, d-1, l}-S I_{f, d, l} \cdot p e_{f}-h i_{f, d, l}+S O_{f, d, l}=0
$$

The emissions level related to the generation schedule of each firm is limited by the number of emission allowances held by the firm:

$$
\begin{array}{|c|c|}
\hline \text { F9 } & \sum_{d, l, p p, m}\left(e r_{p p, p} \cdot G_{p p, m, l} \cdot o_{p p, f}\right)-p c_{f, p} \leq 0 \\
\hline
\end{array}
$$

Similarly, the number of green certificates that each firm may sell is limited by its level of renewable-based production. Note that large hydropower is not considered as a renewable source:

$\mathbf{F 1 0} \quad r t_{f}-\sum_{d, l, p p, m, r e}\left(G_{p p, m, l} \cdot o_{p p, f} \cdot t_{p p, r e}\right)-\sum_{d, l} S O_{f, d, l}+\sum_{d, l}\left(S I_{f, d, l} \cdot p e_{f}\right) \leq 0$ 
The two final constraints of the generators represent the limitations of each power plant to production change, namely the ramp-up and ramp-down constraints:

\begin{tabular}{|l|c|}
\hline F11 & $\sum_{m} G_{p p, m, d, l}-\sum_{m} G_{p p, m, d, l-1}-r u_{p p} \leq 0$ \\
\hline $\mathbf{F 1 2}$ & $\sum_{m} G_{p p, m, d, l-1}-\sum_{m} G_{p p, m, d, l}-r d_{p p} \leq 0$ \\
\hline
\end{tabular}

\subsection{Equilibrium problem}

The MCP problem that defines the model is based on the relationships given in the previous section. The KKT conditions are derived along with market clearing conditions. The KKT conditions are obtained from the derivatives of the Lagrange function with respect to the variables and the multipliers (also called "shadow prices") of the specific constraints of each problem.

The resulting KKT conditions of a firm's problem are given by the following set of equations:

\begin{tabular}{|c|c|}
\hline$\Gamma_{1}$ & $\begin{array}{l}\sum_{f}\left(P_{m, d, l}^{E} \cdot o_{p p, f} \cdot i_{p p, m}\right)+\sum_{f}\left(\frac{1}{e l_{m}} \cdot\left(1+c v_{f, m, d, l}\right) \cdot \frac{G_{p p, m, d, l} \cdot o_{p p, f} \cdot i_{p p, m}}{\sum_{p p}\left(G_{p p, m, d, l} \cdot o_{p p, f} \cdot i_{p p, m}\right)} \cdot P_{m, d, l}^{E} \cdot o_{p p, f} \cdot i_{p p, m}\right) \\
-\sum_{f}\left(\left(\sum_{p}\left(e r_{p p, p} \cdot \operatorname{exopp}_{p}\right)+o c_{p p, m}+\frac{\sum_{t}\left(f p_{m, t} \cdot t_{p p, t}\right)}{e_{p p}}\right) \cdot o_{p p, f}\right) \\
+\sum_{f, t}\left(p r_{t, m} \cdot t_{p p, t} \cdot o_{p p, f}\right)+\sum_{f}\left(\gamma_{f, m, d, l}^{F 2} \cdot o_{p p, f} \cdot i_{p p, m}\right)-\gamma_{p p, d, l}^{F 3}-\sum_{f, p}\left(\gamma_{f, p}^{F 9} \cdot e r_{p p, p} \cdot o_{p p, f}\right) \\
+\sum_{f, r e}\left(\gamma_{f}^{F 10} \cdot o_{p p, f} \cdot t_{p p, r e}\right)-\gamma_{p p, d, l}^{F 11}+\gamma_{p p, d, l-1}^{F 11}-\gamma_{p p, d, l-1}^{F 12}+\gamma_{p p, d, l}^{F 12} \leq 0 \perp G_{p p, m, d, l} \geq 0\end{array}$ \\
\hline$\Gamma_{2}$ & $-P_{\cdot D A M^{\prime}, d, l}^{E} \cdot s_{D_{D A M^{\prime}}}+0-\gamma_{f, D A M^{\prime}, d, l}^{F 2} \cdot s_{\cdot D A M^{\prime}}-\gamma_{f, d, l}^{F 6}+\gamma_{f, d, l}^{F 8} \cdot p e_{f}-\gamma_{f}^{F 10} \cdot p e_{f} \leq 0 \perp S I_{f, d, l} \geq 0$ \\
\hline$\Gamma_{3}$ & $P_{P^{D A M}, d, l}^{E} \cdot S_{D_{D A M^{\prime}}}+0+\gamma_{f, D A M^{\prime}, d, l}^{F 2} \cdot S_{D_{D A M^{\prime}}}-v o w-\gamma_{f, d, l}^{F 7}-\gamma_{f, d, l}^{F 8}+\gamma_{f}^{F 10} \leq 0 \perp S O_{f, d, l} \geq 0$ \\
\hline$\Gamma_{4}$ & $\gamma_{f, d, l}^{F 4}-\gamma_{f, d}^{F 5}-\gamma_{f, d,}^{F 8}+\gamma_{f, d, l-1}^{F 8}+\sum_{l l=H 1}^{l l=H 24} \gamma_{f, d-1, l}^{F 8}=0 \perp S L_{f, d, l} \quad$ free \\
\hline$\Gamma_{5}$ & $-\sum_{p p}\left(G_{p p, m, d, l} \cdot o_{p p, f} \cdot i_{p p, m}\right)-\left(S O_{f, d, l}-S I_{f, d, l}\right) \cdot s_{m} \leq 0 \perp \gamma_{f, m, d, l}^{F 2} \geq 0$ \\
\hline$\Gamma_{6}$ & $\sum_{m} G_{p p, m, d, l}-c i_{p p} \cdot c f_{p p, d, l} \leq 0 \perp \gamma_{p p, d, l}^{F 3} \geq 0$ \\
\hline
\end{tabular}




\begin{tabular}{|c|c|}
\hline$\Gamma_{7}$ & $s m_{f}-S L_{f, d, l} \leq 0 \perp \gamma_{f, d, l}^{F 4} \geq 0$ \\
\hline$\Gamma_{8}$ & $S L_{f, d, l}-s c_{f} \leq 0 \perp \gamma_{f, d, l}^{F 5} \geq 0$ \\
\hline$\Gamma_{9}$ & $S I_{f, d, l}-p c_{f, l} \leq 0 \perp \gamma_{f, d, l}^{F 6} \geq 0$ \\
\hline$\Gamma_{10}$ & $S O_{f, d, l}-s o c_{f, l} \leq 0 \perp \gamma_{f, d, l}^{F 7} \geq 0$ \\
\hline$\Gamma_{11}$ & $S L_{f, d, l}-S L_{f, d, l-1}-\sum_{l l=H 1}^{l=H 24} S L_{f, d-1, l}-P I_{f, d, l} \cdot p e_{f}-h i_{f, d, l}+S O_{f, d, l}=0 \perp \gamma_{f, d, l}^{F 8} f r e e$ \\
\hline$\Gamma_{12}$ & $\sum_{d, l, p p, m}\left(e r_{p p, p} \cdot G_{p p, m, d, l} \cdot o_{p p, f}\right)-p c_{f, p} \leq 0 \perp \gamma_{f, p}^{F 9} \geq 0$ \\
\hline$\Gamma_{13}$ & $r t_{f}-\sum_{d, l, p p, m, r e}\left(G_{p p, m, d, l} \cdot o_{p p, f} \cdot t_{p p, r e}\right)-\sum_{d, l} S O_{f, d, l}+\sum_{d, l}\left(S I_{f, d, l} \cdot p e_{f}\right) \leq 0 \perp \gamma_{f}^{F 10} \geq 0$ \\
\hline$\Gamma_{14}$ & $\sum_{m} G_{p p, m, d, l}-\sum_{m} G_{p p, m, d, l, l-1}-r u_{p p} \leq 0 \perp \gamma_{p p, d, l}^{F 11} \geq 0$ \\
\hline$\Gamma_{15}$ & $\sum_{m} G_{p p, m, d, l,-1}-\sum_{m} G_{p p, m, d, l}-r d_{p p} \leq 0 \perp \gamma_{p p, d, l}^{F 12} \geq 0$ \\
\hline
\end{tabular}

Note that the equation $\Gamma_{1}$ contains the exogenous conjectural variation parameter which is used to model the behaviour (either price-taker or strategic) of the generation companies. This is a typical approach for Cournot-based models with the inclusion of Conjectural Variations. This term is derived from the following general expression (Mas-Colell et al. 1995; Kamiński 2011):

$$
\frac{\partial \Pi_{f}}{\partial q_{f}}=p+p \cdot \frac{q_{f}}{q} \cdot \frac{q \cdot \partial p}{p \cdot \partial q}\left(1+C V_{f}\right)-\frac{\partial c_{f}}{\partial q_{f}}=p \cdot\left(1+\frac{s_{f}}{\varepsilon}\left(1+C V_{f}\right)\right)-\frac{\partial c_{f}}{\partial q_{f}}=0
$$

$\stackrel{\leftrightarrow}{\leftrightarrow} f \quad-$ index of electricity producer,

$p \quad-$ electricity price,

$q_{f} \quad-$ electricity production,

$C V_{f}-$ conjectural variation (for more information on its derivation and interpretation, please see Mas-Colell et al. 1995),

$s_{f} \quad-$ market share,

$\frac{\partial c_{f}}{\partial q_{f}}-$ marginal costs,

$\varepsilon \quad-$ price elasticity of supplies.

Documentation from prior research confirms that there have been several attempts to estimate the appropriate value of the price elasticity of electricity demand. An analysis of 
econometric studies indicates the complexity of the problem and the difficulty in the selection of appropriate values. However, a review of existing electricity market models such as: Schill and Kemfert (2011), Lise et al. (2008), Lise et al. (2006), Borenstein and Bushnell (1999) - also shows that the widely accepted value is -0.4 . Since this value is not significantly different from the results of econometric studies (Table 4), the price elasticity of electricity demand is proposed to be assumed at the level of -0.4 .

Table 4. Results of econometric studies on estimations of price elasticity of demand for electricity

Table 4. Wyniki badań elektrometrycznych wskaźnika elastyczności cenowej popytu na energię elektryczną

\begin{tabular}{|l|c|c|c|c|}
\hline & Country & Years & Short run & Long run \\
\hline Bentzen and Engsted (1993) & Denmark & $1948-1990$ & -0.14 & -0.47 \\
\hline Silk and Joutz (1997) & USA & $1949-1993$ & -0.63 & -0.48 \\
\hline Beenstock et al. (1999) & Israel & $1965-1995$ & - & -0.43 \\
\hline Hondroyiannis (2004) & Greece & $1986-1999$ & - & -0.41 \\
\hline Rapanos and Polemis (2006) & Greece & $1965-1999$ & -0.31 & -0.60 \\
\hline Halicioglu (2007) & Turkey & $1968-2005$ & -0.33 & -0.52 \\
\hline Zachariadis and Pashourtidou 2007 & Cyprus & $1960-2004$ & -0.10 & -0.43 \\
\hline
\end{tabular}

Source: Jamil and Ahmad 2011

Finally, the market clearing conditions of each power market are defined as follows:

$$
\begin{array}{|c|c|c|}
\hline \mathrm{MC}_{1} & \sum_{[m \cdot d \cdot l]}\left(G_{p p, m, d, l} \cdot o_{p p, f} \cdot i_{p p, m}\right) \cdot(1-p l)+\sum_{f}\left(\left(S O_{f, d, l}-S I_{f, d, l}\right) \cdot s_{m}\right) \geq D_{m, d, l}^{*} \cdot\left(\frac{P_{m, d, l}^{E}}{P_{m, d, l}^{*}}\right)^{-e l_{m}}
\end{array}
$$

The model is implemented in the General Algebraic Modelling System (GAMS) (Brooke, Kendrick and Meeraus 1992) as a Mixed Complementary Problem (MCP), and the numerical solution is found with the application of the PATH solver (Dirkse and Ferris 1995; Ferris and Munson 2000; Rutherford 2002).

An MCP is a generalization of a pure, Nonlinear Complementarity Problem (NCP). The MCP formulation also allows for non-zero lower bounds as well as upper bounds to the variables for which a solution must be determined. In an MCP, a vector $x$ must be determined, so that:

$$
0 \leq x \perp F(x) \geq 0
$$

where the $\perp$ ("perp") symbol indicates that $x$ is complementary to the function $F(x)$. To facilitate comparison with the MCP formulation, another way to put this is that for each element $x_{i}$ :

$$
x_{i}>\rightarrow F_{i}(x)=0
$$




\section{Model capabilities}

The model is capable of running scenarios and providing a quantitative analysis of fuel supplies to the power sector given various market structures, which is of significant importance when considering the current organisation of the fuel and energy sectors. Therefore, it is possible to consider how the change in ownership of power companies would affect fuel consumption in the electricity generation sector.

Consequently, based on results of model computation, the level of consumption of primary energy carriers is derived using the following expression:

$$
f_{c_{f u}}=\sum_{t}\left(\sum_{p p}\left(\frac{\sum_{m, d, l} G_{p p, m, d, l}}{e_{p p}} \cdot t_{p p, t}\right) \cdot f t_{t, f u}\right) \cdot 3.6
$$

This model allows one to investigate also the effects of changes in the following exogenously assumed scenario settings:

- installed power generation capacity for each power unit existing in the Polish power sector,

- availability/capacity factors,

- fuel prices for each fuel that can be consumed in the power sector,

- share of bilateral/spot electricity trading,

- demergers, mergers, and acquisitions,

- renewable electricity support schemes,

- renewable electricity targets,

- emission limits,

- emission taxes.

Moreover, the model is fully capable of running scenarios that would enable examinations of the impact of deployment of new technologies in the Polish power generation sector, also those that include Carbon Capture and Storage (CCS) (Bartela and Kotowicz 2010; Bartela et al. 2012; Bartela and Skorek-Osikowska 2010) on consumption of primary energy carriers.

\section{Conclusions}

The problem of fuels' consumption in the power sector has been already studied in the context of environmental regulations, technological progress, and several other circumstances. However, the issue of primary energy supplies to the power sector, given a variety of market structures, has not seen sufficient attention from the research community. Therefore, this paper has formulated a computable model that enables such analyses to be carried out. 
The research presented in this article will be further complemented with data collection and the calibration of the model. Once those tasks are completed, the tool will be ready to employ for analyses that are outlined in the previous sections of this paper.

\section{REFERENCES}

Bartela et al. 2012 - Bartela, Ł., Skorek-Osikowska, A., Kotowicz, J. 2012. Integracja bloku elektrociepłowni węglowej na parametry nadkrytyczne z instalacją wychwytu dwutlenku węgla oraz turbiną gazową. Rynek Energii 100(3), s. 56-62.

Bartela, Ł. and Kotowicz, J. 2011. Wpływ prowadzenia membranowego procesu separacji $\mathrm{CO}_{2}$ na efektywność nadkrytycznej elektrociepłowni węglowej. Rynek Energii 6(97).

Bartela, Ł. and Skorek-Osikowska, A. 2010. Analiza termodynamiczna wybranej struktury elektrociepłowni węglowej na parametry nadkrytyczne. Rynek Energii 90(5), s. 62-8.

Beenstock et al. 1999 - Beenstock, M., Goldin, E. and Nabot, D. 1999. The demand for electricity in Israel. Energy Economics 21(2), pp. 168-183.

Bentzen, J. and Engsted, T. 1993. Short- and long-run elasticities in energy demand. Energy Economics 15(1), pp. 9-16.

Borenstein, S. and Bushnell, J. 1999. An empirical analysis of the potential for market power in California's electricity industry. Journal of Industrial Economics 47(3), pp. 285-323.

Brooke et al. 1992 - Brooke, A., Kendrick, D. A. and Meeraus, A. 1992. GAMS Users' Guide, Release 2.54. San Francisco: The Scientific Press.

Dirkse, S.P. and Ferris, M.C. 1995. The PATH Solver: A Non-monotone stabilization scheme for Mixed Complementarity Problems. Optimization Methods and Software 5(2), pp. 123-156.

Ferris, M.C. and Munson, T.S. 2000. Complementarity problems in GAMS and the PATH solver. Journal of Economic Dynamics and Control 24(2), pp. 165-188.

Gawlik, L. ed. 2013. Węgiel dla polskiej energetyki w perspektywie 2050 roku-analizy scenariuszowe. Katowice: Wyd. IGSMiE PAN, 299 p. (in Polish).

Halicioglu, F. 2007. Residential electricity demand dynamics in Turkey. Energy Economics 29(2), pp. 199-210.

Hondroyiannis, G. 2004. Estimating residential demand for electricity in Greece. Energy Economics 26(3), pp. 319-334.

Iwicki et al. 2014 - Iwicki, K., Janusz, P. and Szurlej, A. 2014. Wpływ liberalizacji rynku gazu ziemnego na bezpieczeństwo energetyczne Polski. Rynek Energii 3(112), s. 3-13.

Jamil, F. and Ahmad, E. 2011. Income and price elasticities of electricity demand: Aggregate and sector-wise analyses. Energy Policy 39(9), pp. 5519-5529.

Kamiński, J. 2011. Market power in a coal-based power generation sector: The case of Poland. Energy 36(11), pp. 6634-6644.

Kamiński, J. 2012. The development of market power in the Polish power generation sector: A 10-year perspective. Energy Policy vol. 42, pp. 136-147.

Kamiński, J. 2014. A blocked takeover in the Polish power sector: A model-based analysis. Energy Policy vol. 66. pp. $42-52$.

Lise et al. 2006 - Lise, W., Linderhof, V., Kuik, O., Kemfert, C., Östling, R. and Heinzow, T. 2006. A game theoretic model of the Northwestern European electricity market-market power and the environment. Energy Policy 34(15), pp. 2123-2136.

Lise et al. 2008 - Lise, W., Hobbs, B.F. and Hers, S. 2008. Market power in the European electricity market - The impacts of dry weather and additional transmission capacity. Energy Policy 36(4), pp. 1331-1343.

Mas-Colell et al. 1995 - Mas-Colell, A., Whinston, M.D. and Green, J.R. 1995. Microeconomic Theory. Oxford University Press, New York.

PSE 2014 - Polish Power System - report 2013. [Online] Available at: http://www.pse.pl/index.php?did = 1717 
Rapanos, V.T. and Polemis, M.L. 2006. The structure of residential energy demand in Greece. Energy Policy 34(17), pp. 3137-3143.

Rutherford, T.F. 2002. Mixed Complementarity Programming with GAMS. Lecture Notes for Econ 6433.

Schill, W. and Kemfert, C. 2011. Modeling Strategic Electricity Storage: The Case of Pumped Hydro Storage in Germany. The Energy Journal 32(3), pp. 59-87.

Siemek et al. 2010 - Siemek, J., Rychlicki, S., Kaliski, M., Szurlej, A. and Janusz, P. 2010. Rola sektora gazowego w zapewnieniu bezpieczeństwa energetycznego Polski na tle wybranych państw Unii Europejskiej. Rynek Energii nr 3, s. 8-13.

Silk, J.I. and Joutz, F.L. 1997. Short and long-run elasticities in US residential electricity demand: a co-integration approach. Energy Economics 19(4), pp. 493-513.

Szurlej, A. and Janusz, P. 2013. Natural gas economy in the United States and European markets. Gospodarka Surowcami Mineralnymi-Mineral Resources Management 29(4), p. 77-94.

Tirole, J. 1988. The Theory of Industrial Organization. The MIT Press, 487 p.

Varian, H.R. 1992. Microeconomic Analysis, 3rd edition. W.W. Norton \& Company, 506 p.

Zachariadis, T. and Pashourtidou, N. 2007. An empirical analysis of electricity consumption in Cyprus. Energy Economics 29(2), pp. 183-198.

ZUŻYCIE ENERGII PIERWOTNEJ W SEKTORZE ENERGETYCZNYM W ZALEŻNOŚCI OD STRUKTUR RYNKOWYCH - PODEJŚCIE MODELOWE

Słowa kluczowe

energia pierwotna, modelowanie, sektor wytwórczy

Streszczenie

W artykule przedstawiono model matematyczny, który możne być zastosowany do badań i analiz dotyczących zużycia energii pierwotnej w sektorze energetycznym dla różnych struktur rynkowych. Choć problematyka ta była już przedmiotem badań w kontekście regulacji środowiskowych czy postępu technologicznego, według najlepszej wiedzy autora wcześniejsze prace nie omawiały problematyki zużycia paliw pierwotnych w zależności od struktur rynkowych. W artykule sformułowano model matematyczny, który umożliwia takie analizy. Model jest oparty na koncepcji teorii gier - zastosowano podejście Cournota z uwzględnieniem oczekiwanych zmian (Conjectural Variations $-\mathrm{CV}$ ). Model został sformułowany jako problem programowania mieszanego komplementarnego (Mixed Complementarity Problem - MCP), który szczególnie nadaje się do modelowania systemów paliwowo-energetycznych w kontekście rynkowym. Przyjęto założenie o uwzględnieniu dwóch hurtowych rynków obrotu energią elektryczną, a mianowicie rynku dnia następnego (RDN) oraz rynku bilateralnego (OTC). Model może być zaimplementowany w dowolnym systemie modelowania wykorzystywanym do budowy matematycznych modeli systemów paliwowo-energetycznych. Oprócz analiz zużycia energii pierwotnej w sektorze energetycznym model będzie mógł być również wykorzystany do analiz ekonomicznych, w szczególności analiz dobrobytu konsumentów i producentów, strat społecznych oraz cen i wielkości produkcji. Badania przedstawione w niniejszym artykule będą kontynuowane, w szczególności w zakresie pozyskania danych i kalibracji modelu. 


\title{
PRIMARY ENERGY CONSUMPTION IN THE POWER GENERATION SECTOR
} AND VARIOUS MARKET STRUCTURES: A MODELLING APPROACH

\author{
Key words
}

primary energy, modelling, power generation sector

\begin{abstract}
This paper presents a computable model that can be applied to examinations of primary energy supplies to the power sector given various market structures. Although a similar problem has been already studied, in particular in the context of environmental regulations and technological progress, it would appear prior works have not approached this issue in the context of market structures. This study has formulated a model that enables such analyses to be carried out. The model developed in this article is based upon the game theory approach; Cournot with the inclusion of conjectural variations. It has been formulated as a Mixed Complementarity Problem (MCP), a general mathematical framework which is particularly well suited for modelling energy systems. The model explicitly distinguishes two wholesale electricity trading platforms, namely the day-ahead (DAM), and the bilateral (OTC) market. The model can be implemented in a modelling systems that are frequently used for development of computable models of power systems. Apart from analyses of primary energy consumption in the power generation sector, the model is capable of carrying out welfare analyses, in particular impact analyses regarding: consumer and producer surpluses, dead weight loss, prices and quantities produced. The research presented in this paper will be further complemented with data collection and calibration of the model.
\end{abstract}

